\title{
EVALUATION OF MATERNAL HEART DISEASE EFFECTS ON MODE OF DELIVERY AND ADVERSE PERINATAL OUTCOMES: A 10 YEARS' EXPERIENCE OF A REFERENCE CENTER
}

\section{Maternal Kalp Hastalığının Doğum Şekli ve Olumsuz Perinatal Sonuçlar Üzerindeki Etkilerinin Değerlendirilmesi: 10 Ylllı Tersiyer Merkez Deneyimi}

\author{
Mehmet Mete KIRLANGIÇ ${ }^{1} \mathbb{D}$, Yusuf MADENDAĞ ${ }^{2} \mathbb{D}^{\mathbb{D}}, \operatorname{Erdem}_{\text {ŞAHIIN }}{ }^{\mathbb{D}}$, \\ Mefkure ERASLAN ŞAHİ ${ }^{3}$ iD, İlknur ÇÖL MADENDAĞ ${ }^{3}$ (D), Gökhan AÇMAZ² (D), \\ Esra AKDEMIR $^{3}{ }^{(D)}$, Merve VURAL YALMAN ${ }^{4}$
}

\author{
${ }^{I}$ Tuzla Devlet Hastanesi, Kadın Hastalıklarl ve Doğum Kliniği, ISTANBUL, TÜRKİYE \\ ${ }^{2}$ Erciyes Üniversitesi Tıp Fakültesi, Kadın Hastalıkları ve Doğum A.D., KAYSERİ, TÜRKIYYE \\ ${ }^{3}$ Kayseri Şehir Hastanesi, Kadın Hastalıklarl ve Doğum A.D., KAYSERİ, TÜRKIYYE \\ ${ }^{4}$ Terme Devlet Hastanesi, Kadın Hastalıklarl ve Doğum Kliniği, SAMSUN, TÜRKIYYE
}

\begin{abstract}
Objective: The aim of the present study was to evaluate the effect of severe maternal cardiac disease during pregnancy on mode of delivery and adverse perinatal outcomes.

Material and Methods: The study comprised 108 pregnant women with cardiac disorder who delivered at a tertiary care center hospital between 2010 and 2020. Mode of delivery, adverse maternal and perinatal outcomes was interpreted according to the woman's status based on her type of heart disease and a modified World Health Organization classification.

Results: The distributions of the women according to the modified World Health Organization classifications were 56.4\%, 26.8\%, $11.2 \%$, and $5.6 \%$ for WHO classes I, II, III, and IV, respectively. The ratios of cardiac diseases were $65.7 \%, 21.2 \%$, and $13.1 \%$, respectively, for rheumatic, and congenital heart disorder, and others. Nulliparity, ethnicity, and history of caesarean section rates were similar among the classes. Gestational age at delivery and birth weight were significantly lower in classes III-IV than in classes I-II. Prematurity, small for gestational age rates, and admission to neonatal intensive care unit were increased in classes III-IV compared to those in classes I-II. While vaginal delivery rates were $54(60 \%)$ in Class I-II and $10(55.5 \%)$ in Class III-IV, the cesarean section rates were $36(40 \%)$ in Class I-II and 8 $(44.5 \%)$ in Class III-IV. There was a significant difference between the cesarean section rates. The presence of adverse obstetrical outcomes was similar among the classes. During this period, a total of 3 maternal mortalities occurred. Maternal morbidity and maternal mortality were increased in classes III-IV compared those in classes I-II.

Conclusion: Pregnant women with cardiac diseases should be administered using a multidisciplinary approach that combines consultants from both obstetrics and cardiology to reduce maternal mortality and morbidity and adverse fetal outcomes.
\end{abstract}

Keywords: Maternal heart disease, $m W H O$ classification, adverse perinatal outcomes, maternal mortality.
ÖZ

Amaç: Bu çalışmanın amacı, gebelik sırasındaki ciddi maternal kalp hastalığının doğum şekli ve olumsuz perinatal sonuçlar üzerindeki etkisini değerlendirmektir.

Gereç ve Yöntemler: 2010-2020 yılları arasında kalp hastalığ1 olup tersiyer bir merkezde doğum yapan 108 gebeyi içermektedir. Gebelerin kalp hastalı̆̆ tipine ve modifiye edilmiş Dünya Sağlık Örgütü sınıflandırmasına göre doğum şekli, olumsuz maternal ve perinatal sonuçlar yorumlandi. Bulgular: Gebelerin modifiye edilmiş Dünya Sağlık Örgütü sinıflamalarına göre dağılımları sınıf I, II, III ve IV'e sırasıyla $\% 56.4, \% 26.8, \% 11.2$ ve $\% 5.6$ olarak saptand. Kardiak patoloji dağılımında romatizmal kalp kapak hastalığ $1 \% 65.7$, konjenital kalp anomalisi \%21.2 ve diğer kalp hastalıkları \%13.1 oranında izlendi. Nulliparite, etnik köken ve sezaryen öyküsü oranları sınıflar arasında benzerdi. Doğumdaki gebelik yaşı ve doğum ağırlığı, sınıf III-IV'te sınıf I-II'ye göre önemli ölçüde daha düşüktü. Sınıf III-IV'te prematürite, gestasyonel yaşa göre küçük olanlar ve yenidoğan yoğun bakım ünitesine yatışın diğer sınıflara göre artmış olduğu görüldü. Sınıf III-IV ve sınıf I-II karşılaştırıldığında vajinal doğum oranları Sınıf I-II de 54 (\%60) iken Sinıf III-IV de 10 (\%55.5) olarak izlendi. Sezaryen sayıları Sinıf I-II de 36 (\%40), Sinif III-IV de 8 (\%44.5) olarak saptandı. Sezaryen sayıları arasında anlamlı bir farklılık mevcuttu. Olumsuz obstetrik sonuçların varlığı benzerdi. Bu periyot diliminde 3 anne ölümü meydana geldi. Anne morbiditesi ve anne ölümü, sınıf I-II'ye kıyasla sınıf III-IV'te daha yüksek olarak gözlendi.

Sonuç: Kardiyak hastalıkları olan gebelere, maternal mortalite ve morbidite yanında olumsuz fetal sonuçları azaltmak için de hem obstetrisyen hem de kardiyolog olacak şekilde multidisipliner bir yaklaşım uygulanmalıdır.

Anahtar Kelimeler: Maternal kalp hastalığ,$\quad m W H O$ sınıflandırması, olumsuz perinatal sonuçlar, anne ölümü 


\section{INTRODUCTION}

Approximately $1-4 \%$ of pregnant women have several types of cardiac disorder and management of these conditions is a challenge for the healthcare professionals who provide care to both the mother and her baby (1). Most often, the women acquire some type of heart disease during pregnancy, which often results in myocardial infarction, heart failure, arrhythmia, or aortic dissection after the birth of their child $(2,3)$. However, perinatal and maternal morbidity and mortality depend on the specific type of cardiac disease, the functional status of the mother, and any complications related to the pregnancy.

Diagnoses are challenging for these women because the cardiovascular symptoms can overlap with those of a normal pregnancy, which may delay identification and subsequent care (4). If the cardiovascular symptoms were considered separately by health care providers, $\geq 25 \%$ of maternal demises could be prevented (4-6). A new study reported that $28.1 \%$ of maternal cardiac deaths were most likely preventable (7). A 2015 report on maternal mortality in the United Kingdom concluded that substandard health care was responsible for $>50 \%$ of deaths from cardiovascular issues, and that $50 \%$ of those were considered to be preventable (8).

With advancements in cardiology and obstetrics, management of these cardiac disorders during pregnancy has improved. However, because of the considerable physiological changes in these women, these advanced treatment options must be provided using a multidisciplinary approach with collaboration from both obstetricians and cardiologists. In addition, management of any cardiovascular disease must begin before conception, and include counseling about the possible risks to both mother and fetus to ensure that optimal conditions are maintained before and during the pregnancy. The aim of this retrospective study was to evaluate maternal and perinatal morbidity and mortality associated with maternal cardiac disease.

\section{MATERIALS AND METHODS}

\author{
Study Population and Study Design
}

This retrospective study was conducted at the Obstetrics Clinic of Erciyes University Medicine Faculty, Turkey. The study protocols complied with the Declaration of Helsinki and were approved by the Erciyes University Clinical Research Ethics Committee (Date: 09.09.2020, issue number: 2020/422). We reviewed the medical records of 108 pregnant women who were diagnosed with heart disease and who delivered at our clinic between January 1, 2010, and January 1, 2020. A multidisciplinary team comprising anesthesiologists, cardiologists, and obstetricians meticulously managed the pregnancies and planned the modes of birth while other medical specialists were included when necessary. If there was missing data on the pregnancy outcome or mode of delivery, the patient was excluded from the study.

The 108 pregnant women were divided into four groups due to the modified World Health Organization (WHO) heart disease classifications of maternal cardiovascular risk (1). Class I indicates a low risk of maternal mortality and morbidity; class II, a low to moderate risk; class III, a high risk, and class IV, extremely high risk and pregnancy contraindicated. The heart team planned the mode of birth, which was classified into either a planned vaginal birth or planned caesarean section. The actual type of delivery was further classified as either vaginal birth or caesarean section, planned or unplanned, based on any perceived complications after the onset of labor. When an assisted vaginal birth or caesarean section was based primarily on obstetrics considering the maternal cardiac history, the conditions were identified as cardiac to prevent any underestimation of the need for cardiac interventions.

Pregnancy outcomes were followed and analyzed between the first antenatal visit and until 6 weeks postpartum. Acute heart failure, worsening preexisting arrhythmia or new onset arrhythmia, or thrombo- 
embolic events and myocardial infarction were defined as maternal cardiac morbidity. Maternal death was defined a death of a woman throughout pregnancy or up to 6 weeks postpartum due to cardiac disease. Pregnancy-induced hypertension; preeclampsia; hemolysis, elevated liver enzymes and low platelets (HELLP) syndrome; gestational diabetes; or postpartum hemorrhages were defined adverse maternal obstetric outcomes. Adverse fetal and neonatal outcomes were small for gestational age (SGA; birth weight $<10$ th percentile), prematurity (i.e., birth $<37$ weeks' gestation), admission into the neonatal intensive care unit (NICU), perinatal and neonatal death. Fetal death after $24^{\text {th }}$ gestational weeks and up to $7^{\text {th }}$ postpartum days was defined as perinatal death. Fetal death after delivery and up to $28^{\text {th }}$ postpartum days was defined as neonatal death.

\section{Statistical analyses}

Study values were expressed as mean \pm standard deviation (SD), median (min-max) or $\mathrm{n}(\%)$. Statistical Package for the Social Sciences version 18 (SPSS 18 Inc, Chicago, IL, USA) was used for all comparisons. For testing the normality assumption of the data, the Shapiro Wilk test was used. The assumption of variance homogeneity was evaluated by the Levene test. Comparison between Class III-IV and Class I-II were made using the Mann Whitney $U$ test. Categorical data was compared using Pearson's Chi-square test or Fisher's exact test. $\mathrm{P}$ values $<0.05$ were considered statistically significant.

\section{RESULTS}

This study comprised 108 pregnant women. Maternal demographic characteristics were shown in Table 1. The distributions of the women according to the $\mathrm{mWHO}$ classifications were $56.4 \%, 26.8 \%, 11.2 \%$, and $5.6 \%$ for mWHO classes I, II, III, and IV, respectively. The ratios of cardiac diseases were $65.7 \%, 21.2 \%$, and $13.1 \%$, respectively, for rheumatic heart disease, congenital heart disease, and others. Mitral regurgitation was the most common valve disorder. Multi-valvular lesions and mitral stenosis were the other most common lesions. A successfully repaired atrial septal defect, ventricular septal defect, or patent ductus artery were the most common congenital heart diseases, and two patients had repaired Tetralogy of Fallot, and one had Epstein anomaly. Other cardiac diseases are provided in Table 2.

A comparison of the delivery characteristics and adverse perinatal outcomes are illustrated in Table 3. Maternal age and body mass index at delivery were significantly higher in classes III-IV than in classes I-II (all $\mathrm{p}<0.001)$. Nulliparity $(\mathrm{p}=0.910)$, ethnicity $(\mathrm{p}=0.890)$, and history of caesarean section rates $(p=0.870)$ were similar among the classes. Gestational age at delivery and birth weight were significantly lower in classes IIIIV than in classes I-II (both $\mathrm{p}<0.001$ ). Prematurity, small for gestational age rates, and admission to NICU were increased in classes III-IV compared to those in classes I-II (all p<0.001). Spontaneous vaginal birth rates $(\mathrm{p}=0.540)$, urgent caesarean section birth rates $(\mathrm{p}=0.680)$ and planned caesarean section birth rates $(\mathrm{p}=0.870)$ were similar among the classes. The presence of adverse obstetrical outcomes was similar among the classes $(p=0.740)$. Maternal morbidity and maternal mortality were increased in classes III-IV compared those in classes I-II (both $\mathrm{p}<0.001$ ). During this period, a total of 3 maternal mortalities occurred. All mortality occurred in the postpartum period. One patient died of dilated cardiomyopathy and heart failure, the other died of severe mitral stenosis and dilated cardiomyopathy. The third patient died in the postpartum period after heart valve replacement surgery due to class IV mitral insufficiency. During this period, 1 neonatal death occurred due to prematurity. 
Table 1: Demographic characteristics of the pregnant women with cardiac disorders

\begin{tabular}{lc}
\hline $\mathrm{N}$ & 108 \\
Age (year) & $30.5 \pm 4.8$ \\
Nulliparity & $31(28.7)$ \\
Body mass index $\left(\mathrm{kg} / \mathrm{m}^{2}\right)$ & $30.5 \pm 3.8$ \\
Ethnicity (Caucasian) & $102(94.4)$ \\
Previous cesarean history & $35(32.4)$ \\
Modified World Health Organization risk classifications & \\
I & $61(56.4)$ \\
II & $29(26.8)$ \\
III & $12(11.2)$ \\
IV & $6(5.6)$ \\
\hline
\end{tabular}

Note: Values are presented as the mean $\pm \mathrm{SD}$, or $\mathrm{n}(\%)$

Table 2: Cardiac disease types for study subjects according to the modified World Health Organization (mWHO) classifications.

\begin{tabular}{|c|c|c|c|c|}
\hline \multirow[t]{2}{*}{ Type } & \multicolumn{4}{|c|}{ mWHO class } \\
\hline & $\mathrm{n}(\%)$ & Class I & Class II & Classes III and IV \\
\hline Rheumatic heart disease & $71(65.7)$ & & & \\
\hline Mitral regurgitation & 21 & 17 & 3 & 1 \\
\hline Mitral stenosis & 9 & 4 & 3 & 2 \\
\hline Aortic regurgitation & 5 & 4 & 1 & - \\
\hline Aortic stenosis & 4 & 1 & 2 & 1 \\
\hline Tricuspid regurgitation & 6 & 6 & - & - \\
\hline Tricuspid stenosis & 2 & 2 & - & - \\
\hline Multivalvular lesions & 19 & 9 & 8 & 2 \\
\hline Prosthetic mechanical valve & 5 & - & - & 5 \\
\hline Congenital heart disease & $23(21.2)$ & & & \\
\hline Successfully repaired ASD, VSD and PDA & 16 & 16 & - & - \\
\hline Unrepaired ASD, VSD and PDA & 4 & - & 4 & - \\
\hline Repaired Fallot tetralogy & 2 & - & 2 & - \\
\hline Ebstein anomaly & 1 & - & 1 & - \\
\hline Others & $14(13.1)$ & & & \\
\hline Arrhythmia & 7 & 2 & 5 & - \\
\hline Dilated cardiomyopathy & 3 & - & - & 3 \\
\hline Hypertrophic cardiomyopathy & 1 & - & - & 1 \\
\hline Pulmonary arterial hypertension & 3 & - & - & 3 \\
\hline
\end{tabular}

Notes: ASD, atrial septal defect; VSD, ventricular septal defect; PDA, patent ductus artery. 
Table 3: Comparison of delivery characteristics and adverse perinatal outcomes.

\begin{tabular}{|c|c|c|c|}
\hline Characteristic & Classes I-II (n=90) & Classes III-IV (n=18) & $P$ value \\
\hline Maternal age (year) & $29.6 \pm 3.7$ & $32.2 \pm 4.1$ & $<0.001$ \\
\hline Nulliparity & $24(26.6)$ & $5(27.7)$ & $0.910^{*}$ \\
\hline BMI at delivery $\left(\mathrm{kg} / \mathrm{m}^{2}\right)$ & $30.4 \pm 2.9$ & $32.6 \pm 3.7$ & $<0.001$ \\
\hline Ethnicity (Caucasian) & $86(95.5)$ & $17(94.4)$ & $0.890 *$ \\
\hline Previous cesarean section history & $29(32.2)$ & $6(33.3)$ & $0.870 *$ \\
\hline \multicolumn{4}{|l|}{ Adverse fetal outcomes } \\
\hline Gestational age at delivery (week) & $39(37-40)$ & $37(35-38)$ & $<0.001$ \\
\hline Prematurity & $6(6.6)$ & $5(27.1)$ & $<0.001^{*}$ \\
\hline Birth weight (g) & $3250 \pm 190$ & $2950 \pm 160$ & $<0.001$ \\
\hline Small for gestational age & $5(5.5)$ & $5(27.7)$ & $<0.001^{*}$ \\
\hline Spontaneous vaginal delivery rates & $54(60)$ & $10(55.5)$ & 0.540 \\
\hline \multicolumn{4}{|l|}{ Cesarian section delivery rates } \\
\hline Urgent & $7(7.8)$ & $2(11.2)$ & $0.680 *$ \\
\hline Planned & $29(32.2)$ & $6(33.3)$ & $0.870^{*}$ \\
\hline Admission to NICU & $2(2.2)$ & $4(22.2)$ & $<0.001^{*}$ \\
\hline Perinatal and neonatal death & - & $1(5.5)$ & NA \\
\hline \multicolumn{4}{|l|}{ Adverse maternal outcomes } \\
\hline Presence of adverse obstetric outcomes & $23(25.5)$ & $5(27.7)$ & $0.740^{*}$ \\
\hline Maternal cardiac morbidity & $1(1.1)$ & $4(22.2)$ & $<0.001 *$ \\
\hline Maternal mortality & - & $3(16.6)$ & $<0.001 *$ \\
\hline
\end{tabular}

BMI: body mass index; NICU: neonatal intensive care unit. NA: not available

Note: Values are presented as the mean $\pm \mathrm{SD}$, or $\mathrm{n}(\%)$, or median (min-max)

\section{DISCUSSION}

Approximately $1-4 \%$ of pregnant women have some type of cardiac disease, and management of these conditions is a challenge for the entire team who provide care to both the mother and fetus (1). The aim of present study was to evaluate the effect of severe maternal cardiac disease during pregnancy on mode of delivery and adverse perinatal outcomes.

In the present study we found that rheumatic heart disorders constitute $65.7 \%$ of cardiac diseases in pregnant women, and that isolated mitral regurgitation was the most common lesion. Multivalvular lesions and mitral stenosis were the other most common lesions. Similar to our findings, other studies by Koşuş et al, Ozel et al and JW Roos-Hesselink et al have shown that mitral regurgitation was in the majority of cases either alone or in combination with other cardiac issues (9-11). The presence of mitral stenosis in classes III-IV is critical, and these patients must be followed up more closely because of the effect of the hemodynamic 
changes during pregnancy. Mitral stenosis limits the amount of blood during diastole and decreases cardiac output. The length of time for diastole is reduced in pregnancy and maternal heart rate increases. Due to these changes, left ventricular filling reduces and these can lead to decreased cardiac output, increased left atrial pressure, and overt cardiac insufficiency. In this study, two of nine pregnant women with functional class IIIIV and rheumatic heart diseases had mitral stenosis as a predominant valve issue.

One study has suggested that pregnancy after any valve replacement is hazardous owing to the maternal and fetal complications that might arise as a result of the use of anticoagulants combined with basic myocardial problems and heart failure (12). Compared to those with bio-prostheses, pregnant women who have mechanical valves also have higher complication rates and adverse events for both mother and child. However, even those with bio-prosthetic valves have had a higher incidence of structural valve insufficiency (13). Five of the women in our study who had mechanical prosthetic valves and who were given anticoagulants were classified as mWHO class III.

In developing countries, more pregnant women with congenital heart disorder are being treated because of increases in the quality of pediatric surgical techniques and neonatal care (14). In the present study, we found that congenital heart diseases constituted $21.2 \%$ of all studied cardiac disorders. Maternal congenital heart diseases are related with neonatal congenital heart disorder, hence for those women a fetal echocardiogram by a fetal cardiologist should be performed (15). One study has shown that different congenital conditions carry specific risks based on their morphological features, previous maternal cardiac surgeries, and current hemodynamic status (16). Cardiomyopathy is a rare condition during pregnancy; however, it is difficult to manage a pregnancy with left ventricular dysfunction owing to the risk of adverse side effects for both the mother and newborn (11). Three of the patients we studied had dilated cardiomyopathy and two of these patients had died. In addition, one patient had hypertrophic cardiomyopathy.

Several published studies have evaluated the adverse effects of heart disorder on fetal and maternal outcomes. Ozel et al have reported that gestational age at delivery and birth weight were significantly lower, and the NICU admission rates (all associated with preterm delivery) were significantly higher in classes III-IV compared to those in classes I-II (10). Madazlı et al have reported no association between adverse fetal outcomes and maternal heart diseases (17). In the present study, we found that gestational age at delivery and birth weight was significantly lower in classes III-IV than in classes I-II based on mWHO classifications. Prematurity, small for gestational age, and admission to NICU were increased in classes III-IV compared to those in classes I-II. In the present study, we found that maternal morbidity and mortality were increased in classes III-IV compared to those in classes I-II.

The optimal type of delivery in women with heart disorder must be managed with a cardiologist, anesthesiologist, and obstetrician. In the present study, the spontaneous vaginal delivery rate in classes I-II was $60 \%$ and caesarean section delivery rate was $40 \%(7.8 \%$ was urgent and $32.2 \%$ was planned caesarean section delivery). In classes III-IV, the spontaneous vaginal delivery rate was $55.5 \%$ and the caesarean section delivery rate was $44.5 \%$ (11.1\% urgent and $33.3 \%$ was planned caesarean section delivery). Vaginal delivery is related to a lower infection risk, hemorrhage and thromboembolism, yet caesarean section provides timing of delivery that can be structured to avoid the risks related with an emergency caesarean section (1820). A planned caesarean section can also minimize the hemodynamic impact on the woman's heart resulting from pain and uterine contractions. On the other hand the effect of general analgesia and regional anesthetics with intubation can induce considerable hemodynamic alterations (21). The European Society of Cardiology 
guidelines suggest that vaginal delivery is usually opted over caesarean section, and that caesarean section is recommended only when there are obstetrical indications and specific high risk cardiac conditions $(19,20)$. We can explain our increased rates of caesarean section in our study as being based on previous caesarean section deliveries, which had indicated caesarean section again for these women.

Considering that maternal morbidity and mortality increased in classes III-IV, pre-pregnancy counseling is more important for these women. All women should receive detailed counseling before pregnancy if they have a known cardiac disease either before conception or early in the pregnancy (19). The risks associated with persistent deterioration of heart function may influence their choice of whether to become pregnant, and these risks for both the mother and offspring should be identified and quantified.

Pregnant women who have cardiac diseases should be managed using a multidisciplinary approach that comprises consultants from both obstetrics and cardiology to reduce maternal morbidity and mortality and improve fetal outcomes. These women should receive pre-pregnancy counseling and, if necessary, cardiac surgery may be indicated before conception.

Conflict of Interest: The authors declare that they have no conflict of interest.

Support and Acknowledgements: There is no funding source.

Researchers' Contribution Rate Statement: The authors declare that they have contributed equally to the article. Concept/Design: ES, MMK; Analysis/interpretation: YM, İCM; Data Collection: MMK, EA, MVY; Writer: ES, MES; Critical Review: GA; Supervision: ES, MMK Ethical Committee Approval: Erciyes University Clinical Research Ethics Committee, date: 09.09.2020, issue number:2020/422).

\section{REFERENCES}

1. Hollier LM, Martin Jr JN, Connolly H, Turrentine M, Hameed A, Arendt KW et al. Pregnancy and heart disease. Obstet Gynecol. 2019;133(5):E320E56.

2. Curry R, Swan L, Steer PJ. Cardiac disease in pregnancy. Curr Opin Obstet Gynecol. 2009;21(6):508-13.

3. Fett JD. Peripartum cardiomyopathy: challenges in diagnosis and management. Expert Rev Cardiovasc Ther. 2016;14(9):1035-41.

4. Hameed AB, Lawton ES, McCain CL, Morton CH, Mitchell C, Main EK et al. Pregnancy-related cardiovascular deaths in California: beyond peripartum cardiomyopathy. Am J Obstet Gynecol. 2015;213(3):379.e1-e10.

5. Gunderson EP, Croen LA, Chiang V, Yoshida CK, Walton D, Go AS. Epidemiology of peripartum cardiomyopathy: incidence, predictors, and outcomes. Obstet Gynecol. 2011;118(3):583-91.

6. Kuklina EV, Callaghan WM. Chronic heart disease and severe obstetric morbidity among hospitalisations for pregnancy in the USA: 19952006. BJOG. 2011;118(3):345-52.

7. Briller J, Koch AR, Geller SE. Maternal cardiovascular mortality in Illinois, 2002-2011. Obstet Gynecol. 2017;129(5):819-26.

8. Cantwell R, Clutton-Brock T, Cooper G, Dawson A, Drife J, Garrod D et al. Saving mothers' lives: reviewing maternal deaths to make motherhood safer: 2006-2008. The eighth report of the confidential enquiries into maternal deaths in the United Kingdom. BJOG. 2011;118:1-203.

9. Köşüş A, Köşüş N, Açıkgöz N, Çapar M. Kalp hastalığ1 olan ve olmayan gebelerde maternal ve fetal sonuçlar açisindan bir fark var mı? Genel Tıp Dergisi. 2008;18(2):55-60. 
10. Ayşegül Ö, Hamzaoğlu K, Durmaz E, Madazlı R. Pregnancy outcomes of 115 cases with maternal heart disease. İstanbul Tip Fakültesi Dergisi. 2020;83(1);17-22.

11. Roos-Hesselink JW, Ruys TP, Stein JI, Thilen U, Webb GD, Niwa K et al. Outcome of pregnancy in patients with structural or ischaemic heart disease: results of a registry of the European Society of Cardiology. Eur Heart J. 2013;34(9):657-65.

12. Pavankumar P, Venugopal P, Kaul U, Iyer K, Das B, Sampathkumar A et al. Pregnancy in patients with prosthetic cardiac valve: a 10-year experience. Scand J Thorac Cardiovasc Surg. 1988;22(1):19-22.

13. Jeejeebhoy FM. Prosthetic heart valves and management during pregnancy. Can Fam Physician. 2009;55(2):155.

14. Thompson JL, Kuklina EV, Bateman BT, Callaghan WM, James AH, Grotegut CA. Medical and obstetric outcomes among pregnant women with congenital heart disease. Obstet Gynecol. 2015;126(2):346.

15. Erolu E, Sarısoy Ö. Fetal echocardiography characteristics in a tertiary center. Erciyes Med J. 2020;42(2):143-6.

16. Drenthen W, Pieper PG, Roos-Hesselink JW, van Lottum WA, Voors AA, Mulder BJ et al. Outcome of pregnancy in women with congenital heart disease: a literature review. J Am Coll Cardiol. 2007;49(24):2303-11.

17. Madazli R, Şal V, Çift T, Guralp O, Goymen A. Pregnancy outcomes in women with heart disease. Arch Gynecol Obstet. 2010;281(1):29.

18. Ruys TP, Roos-Hesselink JW, Pijuan-Domènech A, Vasario E, Gaisin IR, Iung B et al. Is a planned caesarean section in women with cardiac disease beneficial? Heart. 2015;101(7):530-6.

19. Endorsed by the European Society of Gynecology tAfEPC, Medicine tGSfG, Members ATF, RegitzZagrosek V, Blomstrom Lundqvist C, Borghi C et al. ESC Guidelines on the management of cardiovascular diseases during pregnancy: the task force on the management of cardiovascular diseases during pregnancy of the European Society of Cardiology (ESC). Eur Heart J. 2011;32(24):314797.

20. Regitz-Zagrosek V, Roos-Hesselink JW, Bauersachs J, Blomström-Lundqvist C, Cifkova R, De Bonis M et al. 2018 ESC Guidelines for the management of cardiovascular diseases during pregnancy: the task force on the management of cardiovascular diseases during pregnancy of the European Society of Cardiology (ESC). Eur Heart J. 2018;39(34):3165241.

21. Elkayam U, Goland S, Pieper PG, Silversides CK. High-risk cardiac disease in pregnancy: part I. J Am Coll Cardiol. 2016;68(4):396-410. 